This Journal is available in Telkom University online Journals

Jurnal Manajemen Indonesia

\title{
Problem Arising from New Technology on E-Government, the Use of Hay.U Application in Bandung, Indonesia
}

\author{
Abdullah Ramdhani ${ }^{1}$, Dini Turipanam Alamanda ${ }^{2}$, Ai Miman Nurdiaman ${ }^{3}$, and Muhammad Arief ${ }^{4}$ \\ ${ }^{1,3}$ Faculty of Social and Political Sciences, Garut University, Garut, Indonesia \\ ${ }^{2}$ Faculty of Economics, Garut University, Garut, Indonesia \\ ${ }^{4}$ Faculty of Economic and Business, Telkom University, Bandung, Indonesia
}

\begin{abstract}
This study aims to discover what has been done by BPPT Bandung in making the implementation the strategy of Integrated Licensing Services Agency to make Hay.U application Bandung to be effective. The factors used to analyze it are PIECES consisting of performance, information, efficiency, control, economy, and service. Using a qualitative approach, interviews with a number of stakeholders were conducted to get a comprehensive overview of the application which presently becomes the mainstay of Bandung city government. The results of this study reveal that Hay.U can overall support the performance of users and employees. In addition, Hay. $U$ is also able to improve the accuracy of information which can make online licensing system in Bandung effective. However, the Integrated Licensing Service Agency (BPPT) needs to consider the convenience factor for the users when inputting data. Users still have problems with the new technology and the amount of data needing to be attached.
\end{abstract}

Keywords - E-Government, Online system, Web-based Application.

\begin{abstract}
Abstrak
Penelitian ini bertujuan untuk mengetahui apa yang telah dilakukan oleh BPPT Bandung dalam mengimplementasikan strateginya untuk menjadikan aplikasi Hay.U Bandung menjadi efektif. Faktor yang digunakan untuk menganalisis data adalah PIECES yang terdiri dari kinerja (performance), informasi (information), efisiensi (efficiency), control (control), ekonomi (economic), dan layanan (service). Dengan menggunakan pendekatan kualitatif, wawancara dengan sejumlah pemangku kepentingan dilakukan untuk mendapatkan gambaran komprehensif dari aplikasi yang saat ini menjadi andalan pemerintah kota Bandung. Hasil penelitian ini mengungkapkan bahwa Hay.U secara keseluruhan dapat mendukung kinerja pengguna dan karyawan. Selain itu, Hay. U juga dapat meningkatkan keakuratan informasi yang dapat membuat sistem lisensi online di Bandung efektif. Namun, BPPT perlu mempertimbangkan faktor kenyamanan bagi pengguna saat memasukkan data. Pengguna masih memiliki masalah dengan penerimaan teknologi baru dan banyaknya data yang perlu dilampirkan.
\end{abstract}

Kata Kunci-E-Government, Sistem daring, Aplikasi Berbasis Web.

\section{INTRODUCTION}

Currently the development of Internet technology has reached a very rapid rate. Internet applications are already used for e-commerce and developed for use in government environments known as e-government. Both central government and local governments are competing to make e-government applications. E-government is the use of information and telecommunication technology for efficient and effective government administration and it provides a transparent and satisfactory service to the society. 
The concept of e-Government is made to anticipate global problems, such as culture, economy, social, law and politics. E-Government refers to the use of information technology by government agencies to connect the government and the society. Most e-Government researches only focus on the developed countries and ignore the emerging economic areas (Munoz \& Bolivar, 2018). The United Nations has reissued the EGDI (EGovernment Development Index) ranking based on the 2016 survey. In 2016, Indonesia ranked 116th of EGDI which is 10 ratings lower than its position in 2014 at the 106th rank. This condition is still far below the other countries in Southeast Asia such as Malaysia (ranked 60th), Philippines (ranked 71st), and Brunei Darussalam (ranked 83rd). Indonesia itself has adopted e-Government system since the issuance of Presidential Instruction No. 3 of 2003 on National Policy and Strategy of e-Government Development. E-Government is still a big job for the Indonesian government.

All government organizations will be affected by the development of e-government. E-government can be classified into four levels. The first level is when the government publishes information through the website. The second level takes place when there is interaction between society and government offices via e-mail. The third level is when the user community can conduct transactions with government offices on a reciprocal basis. The last level takes place when there is integration across government offices so that people can use it to conduct transactions with all the government offices that have already shared the database. Responding to that, Bandung city government should of course be able to utilize the progress of ICT in improving the quality of public services more effectively and efficiently. However, it cannot be denied that to divert the administration from a manual-based to electronics requires a relatively large process and effort.

Bandung Smart city is a city concept that has integrated connections in various fields to provide practical and efficient impacts in urban management ranging from congestion prevention problems, waste accumulation, repairs of damaged roads, soil contour information to find out whether an area is suitable for buildings or agriculture. Mayor of Bandung, Kamil said that technology-based innovation becomes the main requirement of public service system in Bandung (Kemendagri, 2018). In fact, he targeted every department to have an online service system to provide convenience to the public. In addition to facilitate citizens, online-based services can also reduce the action of brokering that has been happening.

In the Year 2014, based on Mayor of Bandung Regulation No. 1171 of 2013 on Procedure of One Stop Integrated Licensing Service (BPPT), BPPT Bandung is in charge of integrated licensing services for 26 types of licenses. One of the online community-based services that BPPT generates is the HAY.U, a licensing service application which can be accessed via smartphones. This application is the development of online unified licensing service system through website named "Hay.U Bandung" which was inaugurated and launched in May 2015. Since then, BPPT has issued 9,000 licenses of 25 types (Kemendagri, 2018). This licensing application comes with a number of features. One of them enables public to monitor the progress of the licensing process they have proposed. In addition, citizens can provide an assessment of the performance of BPPT.

George (2004) said that government's performance needs monitoring and evaluation. Careful monitoring can lead to improvement of objectives, measures, performance targets, collection procedures, reporting forms, and improvement plans in responding to a certain problem, and under different conditions. So, the question concerning the Hay.U Bandung is: What is done by BPPT Bandung to implement effective licensing information services through Hay.U Bandung?

\section{LITERATURE REVIEW}

\section{A. Smart City}

Munoz and Bolivar (2018) said that smart city is a place where information technology is gripped to address both old and new problems. In the past, Townsend (2013) said that buildings and infrastructure flew goods in a rigid and certain way. But smart city can adapt quickly, by feeding on a wide array of sensors, providing data input into the software which can see the big picture and then take action.

The concept of Internet of Things (IoT) succeeded in bringing up what are called smart cities which support the city's operational activities smartly by eliminating human hands. Smart city emerged as a solution to address the challenges arising from the growing urbanization and exponential populations. Unfortunately, smart cities are still unevenly developing in the world due to technological, economic and governmental barriers (Silva et al, 2018). 


\section{B. Smart Goverment}

Giffinger (2008) said that states that smart government is a part of smart city that specializes in governance. It includes all terms, criteria, and objectives for the process of empowerment and participation of both the society and government simultaneously. Researches on smart government in Bandung are among others concerning the communication effectiveness of Bandung mayor (Nadapdap et al, 2015), Social Network Analysis (Alamanda et al, 2016), and entrepreneurship program (Cahyaningrum et al, 2018). Stages of EGovernment according to Presidential Instruction No. 3 of 2003 in Hardjaloka (2014) are on national development policies and strategies, that the implementation of E-Government can be implemented through the following levels:

1) Preparation stage which includes:

a. Creation of information websites in each institution;

b. HR Setup;

c. Preparing easy access facilities such as providing the facilities of multipurpose community centers, internet cafes, and so on;

d. Socialization of information websites for both internal and public.

2) Maturity stage which includes:

a. Creating interactive public information websites;

b. Making inter-linkages with other institutions.

3) Consolidation stage which includes:

a. Creation of public service transaction websites;

b. Making interoperability of applications and data with other institutions.

4) Utilization stage which includes the creation of integrated applications for G2G (Government to Government) services, G2B (Government to Business) and G2C (Government to Citizen)

\section{Challenges and Problems of E-Government in Developing Countries}

Previous research has demonstrated the failure of e-Government implementation in developing countries carried out by the local governments (Munoz and Bolivar, 2018). For example, Zhao et al. (2012) explains that many developing countries have developed project plans that show weak project scope, unrealistic goals and weaknesses of conformity with corporate / organizational goals.

Reddict (2011) state that regional regulation which regulates the implementation of E-government:

1) There is no tradition of sharing information;

2) There is no documentation tradition yet;

3) Lack of reliable human resources and people's ability to use technology;

4) Expensive and inadequate infrastructure;

5) Limited access.

\section{PIECES Analysis}

Based on the theory put forward by Whitte (2014), performance is a system capability in completing a task quickly and the goals can be achieved. Performance is measured by the volume of work and response time. Information is important because it assists management and users to determine the next job step. Information is measured by how up-to-date, relevant, and accurate it is. Efficiency is related to how the source can be used optimally which can be measured by the amount of time wasted, whether the data is inputted or processed excessively, and the effort needed to complete the task. This involves increased controls to detect and fix the errors and frauds that will possible occur such as data privacy. Economy is the cost incurred from the utilization of information. An increase in economic needs can affect both cost and benefit controls. Service covers the enhancement of services provided by the system, it can be data accuracy and consistency, and ease of use for the users. This research framework is then compiled and shown in Figure 1. 


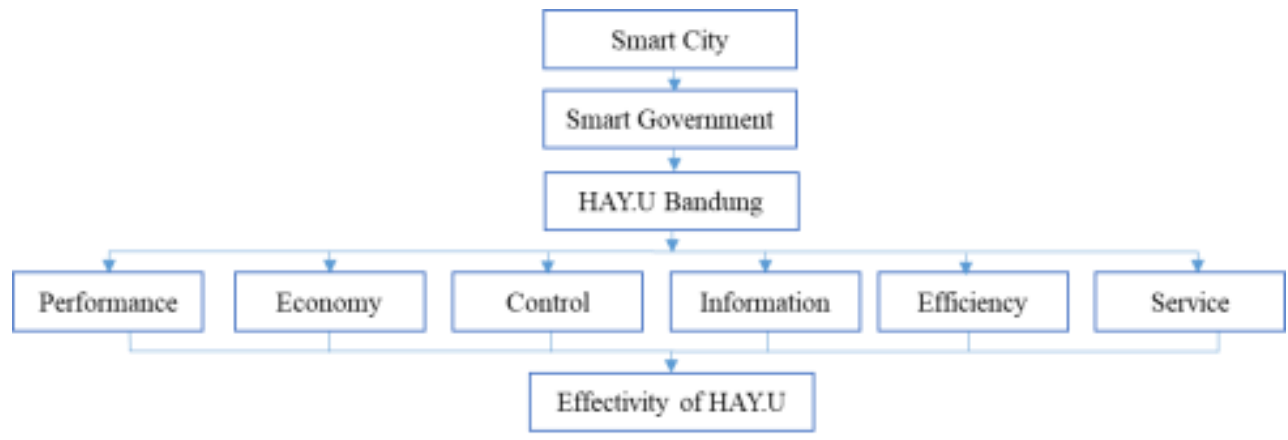

Figure 1. Conceptual Framework

\section{METHODOLOGY}

This study used a descriptive qualitative method. The organizational analysis unit is the BPPT of Bandung City, Goldstein \& Pevehouse (2014), there are four levels of analysis, i.e., individual analysis, domestic analysis, inter-country analysis and global analysis. The analysis is then tailored to the required benefits. Based on the time, this study is cross-sectional or a one-time research which means that the data collection is done at a certain point. Through a number of data retrieval techniques such as observation, interview and literature study, this study was conducted for 2 months. Key persons were selected through a purposive sampling method, and four informants were selected through in-depth interviews. The profile of informants is provided on Table 1 .

Table 1. Informant's Profile

\begin{tabular}{cl}
\hline Initial & \multicolumn{1}{c}{ Position } \\
\hline YE & Head of Section for Information and Complaints Section in BPPT \\
RM & Staff of Integrated Service and Licensing Agency in BPPT \\
A & User 1 (government employee) \\
L & User 2 (business owner) \\
ES & User 3 (private) \\
\hline
\end{tabular}

In this study, PIECES Analysis (performance, information, economy, control, efficiency and service) popularized by Whitte (2004) is used. The analyzed system is used to find some major problems or problems that are initial of the main problem; therefore this analysis is very important to identify an information system. To compile the PIECES study on the HAY.U system, a number of indicators are used as presented in Table 2. Furthermore, the resulted data is inputted into an ATLAS Ti.7 analysis tool and stages such as trustworthiness are done by triangulating sources, techniques and time and discussing with the researchers of Bandung smart city.

Table 2. Indicators of PIECES

\begin{tabular}{cll}
\hline No. & \multicolumn{1}{c}{ Factor } & \multicolumn{1}{c}{ Indicator } \\
\hline 1. & Performance & 1) Job Volume \\
& & 2) \\
2. & Information & 1) Up to date \\
& & 2) Relevant \\
& & 3) Accurate \\
3. & Economy & 1) Input Data \\
& & 2) Effort \\
4. & Control & Privacy Data \\
5. & Efficiency & Cost \\
6. & Service & 1) Accuracy \\
& & 2) Easy to Use \\
\hline
\end{tabular}




\section{RESULT AND DISCUSSION}

There are four stages in the e-Government process of change or implementation:

1) Presence: at this stage, one-way communication between government, society and interested parties takes place through the use of internet technology ;

2) Interaction: in this second stage, two-way direct communication starts happening between the government and those who are concerned through the use of media such as intranets and multimedia facilities. Every individual can connect with anyone of government representatives effectively and efficiently ;

3) Transaction: transactions occur when there is an exchange process of goods or services through the virtual world involving the resources of finance, human, information, and so forth ;

4) Integration: the last process is integration in which government can be connected with companies, universities, non-governmental institutions, governments of other countries, and others. The integration with government occurs at the level of processes, data and technology.

The results of the interview data processing using ATLAS Ti.7 are presented in Table 3. to Table 8.

\section{A. Performance}

Table 3. Quotation Results on the Variable of Performance

\begin{tabular}{|c|c|c|c|c|}
\hline \multirow{2}{*}{ No } & \multirow{2}{*}{ Statement } & \multirow{2}{*}{ Quotation } & \multicolumn{2}{|c|}{ Effective } \\
\hline & & & Yes & No \\
\hline \multicolumn{5}{|c|}{ Job Volume } \\
\hline 1. & $\begin{array}{l}\text { The performance of Integrated Licensing } \\
\text { Service Agency is now much different, it } \\
\text { can be seen through the increasing } \\
\text { demand for information and growing } \\
\text { number of complaints which is } \\
\text { supported by } 7 \text { channels. }\end{array}$ & $\begin{array}{l}\text { «The request for information and } \\
\text { the number of complaints have } \\
\text { actually increased» (respondent } \\
\text { 1) }\end{array}$ & $\sqrt{ }$ & \\
\hline 2. & $\begin{array}{l}\text { Users find it easier to apply. Although at } \\
\text { first they are still confused with what to } \\
\text { do }\end{array}$ & $\begin{array}{l}\text { «I find it easier to apply» } \\
\text { (respondent 2) }\end{array}$ & $\sqrt{ }$ & \\
\hline 3. & $\begin{array}{l}\text { Users do not postpone work because of } \\
\text { having other business. }\end{array}$ & $\begin{array}{l}\text { "I did not delay because at that } \\
\text { time I wanted to leave Indonesia " } \\
\text { (respondent } 3 \text { ) }\end{array}$ & $\sqrt{ }$ & \\
\hline 4. & $\begin{array}{l}\text { Users do not postpone licensing, as it } \\
\text { should be done. }\end{array}$ & $\begin{array}{l}\text { "Of course I did not postpone it } \\
\text { because business permissions } \\
\text { should be resolved soon" } \\
\text { (respondent } 4)\end{array}$ & $\sqrt{ }$ & \\
\hline
\end{tabular}

\section{Response Time}

Each performance has a standard time of service. Through the online system, for 5 example, it takes a maximum of 3 work days to request information and submit complaints.

The existence of Hay.U Bandung makes the licensing process faster.
"That's much different, The use of this online application for information requests and $\sqrt{ }$ complaints actually increases. "

(respondent 1)

«I think it's faster»

(respondent 2) 


\begin{tabular}{|c|c|c|c|c|}
\hline \multirow{2}{*}{ No } & \multirow{2}{*}{ Statement } & \multirow{2}{*}{ Quotation } & \multicolumn{2}{|c|}{ Effective } \\
\hline & & & Yes & No \\
\hline 7 & $\begin{array}{l}\text { Through the online system, licencing } \\
\text { registration can be done from home. }\end{array}$ & $\begin{array}{l}\text { "When online, yes it is nice to } \\
\text { register from home» } \\
\text { (respondent } 3 \text { ) }\end{array}$ & $\sqrt{ }$ & \\
\hline 8 & $\begin{array}{l}\text { Users can apply for business licenses and } \\
\text { monitor the files anywhere. }\end{array}$ & $\begin{array}{l}\text { «It's easier to complete » } \\
\text { (respondent } 4)\end{array}$ & $\sqrt{ }$ & \\
\hline
\end{tabular}

\section{B. Information}

Table 4. Quotation Results on the Variable of Information

\begin{tabular}{|c|c|c|c|c|}
\hline \multirow{2}{*}{ No } & \multirow{2}{*}{ Statement } & \multirow{2}{*}{ Quotation } & \multicolumn{2}{|c|}{ Effective } \\
\hline & & & Yes & No \\
\hline 1. & $\begin{array}{l}\text { The information provided by the Integrated } \\
\text { Licensing Service Agency is always } \\
\text { updated, depending on the information } \\
\text { required by consumers and the } \\
\text { government's standard rules. }\end{array}$ & $\begin{array}{l}\text { "We have to update the } \\
\text { online Information } \\
\text { constantly" } \\
\text { (respondent } 1 \text { ) }\end{array}$ & $\sqrt{ }$ & \\
\hline 2. & $\begin{array}{l}\text { Users feel the information provided is } \\
\text { sufficient. }\end{array}$ & $\begin{array}{l}\text { "I think the information } \\
\text { provided is sufficient" } \\
\text { (respondent 2) }\end{array}$ & $\sqrt{ }$ & \\
\hline 3. & $\begin{array}{l}\text { Users feel the information is good enough } \\
\text { and clear. }\end{array}$ & $\begin{array}{l}\text { “It's good enough and } \\
\text { clear” } \\
\text { (respondent } 3 \text { ) }\end{array}$ & $\sqrt{ }$ & \\
\hline 4. & Users feel the information is easy to gain & $\begin{array}{l}\text { "For the information, } \\
\text { it's easy enough to get " } \\
\text { (respondent } 4 \text { ) }\end{array}$ & $\sqrt{ }$ & \\
\hline
\end{tabular}

C. Economy

Table 5. Quotation Results on the Variable of Economy

\begin{tabular}{|c|c|c|c|c|}
\hline \multirow{2}{*}{ No } & \multirow{2}{*}{ Statement } & \multirow{2}{*}{ Quotation } & \multicolumn{2}{|c|}{ Effective } \\
\hline & & & Yes & No \\
\hline \multicolumn{5}{|c|}{ Input Data } \\
\hline 1. & $\begin{array}{l}\text { The Licensing Service Agency has a } \\
\text { third party for the management of } \\
\text { Hay.U Bandung }\end{array}$ & $\begin{array}{l}\text { "There is a third party } \\
\text { for our information } \\
\text { system» } \\
\text { (respondent } 1 \text { ) }\end{array}$ & $\sqrt{ }$ & \\
\hline 2. & When making the first online & «I was still confused at & & $\sqrt{ }$ \\
\hline
\end{tabular}




\begin{tabular}{|c|c|c|c|c|}
\hline \multirow{2}{*}{ No } & \multirow{2}{*}{ Statement } & \multirow{2}{*}{ Quotation } & \multicolumn{2}{|c|}{ Effective } \\
\hline & & & Yes & No \\
\hline & submission, Users are still confused. & $\begin{array}{l}\text { the first time » } \\
\text { (respondent 2) }\end{array}$ & & \\
\hline 3. & $\begin{array}{l}\text { Users feel nothing is excessive when } \\
\text { inputting data. Because in the past } \\
\text { there were many requirements. }\end{array}$ & $\begin{array}{l}\text { "I do not think there is } \\
\text { any exaggeration » } \\
\text { (respondent } 3 \text { ) }\end{array}$ & $\sqrt{ }$ & \\
\hline 4. & $\begin{array}{l}\text { Users are confused because there are } \\
\text { many things needed to upload to } \\
\text { complete the licencing requirements. }\end{array}$ & $\begin{array}{l}\text { "I am confused because } \\
\text { there are so many things } \\
\text { to upload» } \\
\text { (respondent } 4 \text { ) }\end{array}$ & & $\sqrt{ }$ \\
\hline
\end{tabular}

\section{Effort}

The different effort of online system "About the effort, of is that the applicants do not need to meet the officers directly.

course through online, we do not need to meet the officers"

(respondent 1)

"It is surely simpler"

6. Users are easier to apply for licenses.

(respondent 2)

Users feel the burden is reduced

7. because they do not need to come to

"I do not need to go to BPPT office"

(respondent 3) Agency.

«Now yeah, we can apply

for licences from

anywhere"

(respondent 4)

\section{Control}

Table 6. Quotation Results on the Variabel of Control with Indicator of Privacy Data

\begin{tabular}{|c|c|c|c|c|}
\hline \multirow{2}{*}{ No } & \multirow{2}{*}{ Statement } & \multirow{2}{*}{ Quotation } & \multicolumn{2}{|c|}{ Effective } \\
\hline & & & Yes & No \\
\hline 1. & $\begin{array}{l}\text { The Integrated Licensing Service } \\
\text { Agency continuously update data } \\
\text { privacy. }\end{array}$ & $\begin{array}{l}\text { "So far it has not been } \\
\text { done, but we do our own } \\
\text { updating constantly" } \\
\text { (respondent } 1 \text { ) }\end{array}$ & $\sqrt{ }$ & \\
\hline 2. & $\begin{array}{l}\text { Users believe that the Integrated } \\
\text { Licensing Service Agency can } \\
\text { guarantee the data provided by } \\
\text { the users. }\end{array}$ & $\begin{array}{l}\text { "BPPT as a government } \\
\text { tool should be able to } \\
\text { guarantee the data we } \\
\text { provide" } \\
\text { (respondent 2) }\end{array}$ & $\sqrt{ }$ & \\
\hline 3. & Users suggest that the ID used is & $\begin{array}{l}\text { "Well, My advice is if } \\
\text { possible, do not use the ID }\end{array}$ & $\sqrt{ }$ & \\
\hline
\end{tabular}




\begin{tabular}{|c|c|c|c|c|}
\hline \multirow{2}{*}{ No } & \multirow{2}{*}{ Statement } & \multirow{2}{*}{ Quotation } & \multicolumn{2}{|c|}{ Effective } \\
\hline & & & Yes & No \\
\hline & not from citizenship ID number. & $\begin{array}{l}\text { from citizenship ID } \\
\text { number" } \\
\text { (respondent } 3 \text { ) }\end{array}$ & & \\
\hline 4. & $\begin{array}{l}\text { Users suggest that the Integrated } \\
\text { Licensing Service Agency does } \\
\text { not publish the user data. }\end{array}$ & $\begin{array}{l}\text { Data that is completely } \\
\text { privacy should not be } \\
\text { published } \\
\text { (respondent } 4 \text { ) }\end{array}$ & $\sqrt{ }$ & \\
\hline
\end{tabular}

\section{E. Efficiency}

Table 7. Quotation Results on the Variable of Efficiency with Cost Indicator

\begin{tabular}{|c|c|c|c|c|}
\hline \multirow{2}{*}{ No } & \multirow{2}{*}{ Statement } & \multirow{2}{*}{ Quotation } & \multicolumn{2}{|c|}{ Effective } \\
\hline & & & Yes & No \\
\hline 1. & $\begin{array}{l}\text { The results obtained are } \\
\text { proportional to the cost incurred. }\end{array}$ & $\begin{array}{l}\text { "The advantages are yes } \\
\text { comparable, in my opinion" } \\
\text { (respondent } 1 \text { ) }\end{array}$ & $\sqrt{ }$ & \\
\hline 2. & $\begin{array}{l}\text { Users feel it is cheaper to apply } \\
\text { for a license using Hay.U } \\
\text { Bandung }\end{array}$ & $\begin{array}{l}\text { "I think it is cheaper" } \\
\text { (respondent 2) }\end{array}$ & $\sqrt{ }$ & \\
\hline 3. & $\begin{array}{l}\text { Users are not too concerned } \\
\text { about the costs incurred. }\end{array}$ & $\begin{array}{l}\text { "For me how much the } \\
\text { price is not a problem, what } \\
\text { is important is the quick } \\
\text { license" } \\
\text { (respondent } 3 \text { ) }\end{array}$ & $\sqrt{ }$ & \\
\hline 4. & The cost is less. & $\begin{array}{l}\text { "The costs incurred online } \\
\text { will certainly save on } \\
\text { expenses" } \\
\text { (respondent } 4 \text { ) }\end{array}$ & $\sqrt{ }$ & \\
\hline
\end{tabular}

F. Service

Table 8. Quotation Results on The Variable of Service

\begin{tabular}{|c|c|c|c|c|}
\hline \multirow{2}{*}{ No } & \multirow{2}{*}{ Statement } & \multirow{2}{*}{ Quotation } & \multicolumn{2}{|c|}{ Effective } \\
\hline & & & Yes & No \\
\hline \multicolumn{5}{|c|}{ Accuracy } \\
\hline 1. & $\begin{array}{l}\text { For accuracy, the } \\
\text { Integrated } \\
\text { Licensing Service } \\
\text { Agency has the } \\
\text { standard rules that } \\
\text { have been issued } \\
\text { by the government. }\end{array}$ & $\begin{array}{l}\text { "If there are changes, it should be } \\
\text { socialized, but if you look at the } \\
\text { regulation it is standard like that" } \\
\text { (respondent } 1 \text { ) }\end{array}$ & $\sqrt{ }$ & \\
\hline
\end{tabular}




\begin{tabular}{|c|c|c|c|c|}
\hline \multirow{2}{*}{ No } & \multirow{2}{*}{ Statement } & \multirow{2}{*}{ Quotation } & \multicolumn{2}{|c|}{ Effective } \\
\hline & & & Yes & No \\
\hline 2. & $\begin{array}{lr}\text { The Integrated } \\
\text { Licensing } & \text { Service } \\
\text { Agency r has } \\
\text { provided accurate } \\
\text { information. }\end{array}$ & $\begin{array}{l}\text { "I think it's accurate” } \\
\text { (respondent 2) }\end{array}$ & $\sqrt{ }$ & \\
\hline 3. & $\begin{array}{l}\text { Users consider } \\
\text { information } \\
\text { provided through } \\
\text { Hay.U Bandung } \\
\text { has } \\
\text { consistent. been }\end{array}$ & $\begin{array}{l}\text { "Yeah, consistent. I think it is" } \\
\text { (respondent } 3 \text { ) }\end{array}$ & $\sqrt{ }$ & \\
\hline 4. & $\begin{array}{l}\text { Users tend to } \\
\text { follow what it } \\
\text { takes in proposing } \\
\text { licenses. }\end{array}$ & $\begin{array}{l}\text { "I just follow what is required for } \\
\text { company licensing" } \\
\text { (respondent } 4 \text { ) }\end{array}$ & & $\sqrt{ }$ \\
\hline \multicolumn{5}{|c|}{ Easy to Use } \\
\hline 5. & $\begin{array}{l}\text { For example, with } \\
\text { this Hay.U we can } \\
\text { see which points } \\
\text { are } \quad \text { already } \\
\text { licensed and } \\
\text { unlicensed. }\end{array}$ & $\begin{array}{l}\text { "We can see which points are licensed } \\
\text { and unlicensed, it is processed like that" } \\
\text { (respondent } 1 \text { ) }\end{array}$ & $\sqrt{ }$ & \\
\hline 6. & $\begin{array}{l}\text { Users feel the } \\
\text { change from the } \\
\text { once complicated } \\
\text { submissions. }\end{array}$ & $\begin{array}{l}\text { "It used to be complicated, now I can } \\
\text { submit by simply attaching the required } \\
\text { documents" } \\
\text { (respondent 2) }\end{array}$ & $\sqrt{ }$ & \\
\hline 7. & $\begin{array}{l}\text { Hay.U Bandung is } \\
\text { an innovation in } \\
\text { licensing service } \\
\text { that ease the users. }\end{array}$ & $\begin{array}{l}\text { "Creating an online licensing innovation } \\
\text { like this is good because it certainly } \\
\text { facilitates the applicants" } \\
\text { (respondent } 3 \text { ) }\end{array}$ & $\sqrt{ }$ & \\
\hline 8. & $\begin{array}{l}\text { It makes it easier } \\
\text { for users to apply } \\
\text { for licenses } \\
\text { compared with the } \\
\text { last system. }\end{array}$ & $\begin{array}{l}\text { It is now easier to deal with licenses than } \\
\text { ever } \\
\text { (respondent } 4 \text { ) }\end{array}$ & $\sqrt{ }$ & \\
\hline
\end{tabular}

Based on the above results, the difficulty for licensing service applicants focuses on the interface that a communication procedure is very important to be considered and implemented correctly to improve service for public through the effective implementation of Hay.U Bandung in the Licensing Service Agency of Bandung. This procedure starts from the website display which is a communication mechanism between the licensing service applicants and the system.

The purpose of interface improvement is to enable the license service applicants to perform every task required to apply for a license. Hay.U Bandung system should not display too much information and too many options to avoid confusion of the applicants. The applicants wish to obtain necessary information when visiting Hay.U Bandung system. Simple and concise words should be used to help the readers understand the licensing information. When accessing Hay.U Bandung system now, there are many licensing options which can cause the applicants to be confused. 
The Hay.U system can also add important points on the general issues faced by the applicants containing popular questions about licensing services. This can save the time of both applicants and employees of the Integrated Licensing Service Agency. These general issues can be used as a reference for the applicants to avoid asking or answering the same questions over and over. Providing the applicants with a flow chart of licensing service procedure will be helpful. The graph can be used if it is not burdensome and relevant to the site. Another component that can be used is links to the relevant websites. Applicants of licensing services may obtain relevant information and may have the desired topic.

\section{CONCLUSION AND RECOMMENDATION}

Based on the results of data processing and the discussion in the research on the strategy of Integrated Licensing Services Agency to make Hay.U Bandung effective, the purpose of this study can be answered which is to find out the steps to be taken by the Integrated Licensing Service Agency. Based on the results of the research, it can be concluded that the performance, information, economy, control, efficiency, and service factors have been in accordance with what is expected by the Bandung Integrated Licensing Service Agency which is to support the works of the users or the employees and to achieve the licensing target. Performance with the indicators of volume and response time has been considered to be effective, information with updated and relevant indicators has also been considered effective. Economy with effort indicator has been considered effective because it facilitates the licensing submission process, but the inputted data indicator should be the focus of Bandung Integrated Licensing Service Agency because this indicator is still a problem for the users when completing the licensing data. Furthermore, the control factor with the data privacy indicator has been said to be effective. And the efficiency factor is considered to have an advantage. Lastly, service factor with the indicators of accuracy and ease of use can be said to be effective for both users and employees when compared with the old system of licensing, the online system of Hay.U Bandung is easy to use.

Suggestions for Bandung City Integrated Licensing Service Agency as the organizer of Hay.U Bandung online system are firstly to provide convenience for the inputted data because the indicator is still an issue for users when applying for a license. Then, to improve the accuracy of the information provided and the data entered to increase the effectiveness of the Hay.U Bandung system. Finally, to maintain and develop the indicators of work volume, response time, updated and relevant information, effort, privacy, and ease of using Hay.U Bandung system.

\section{REFERENCES}

Alamanda, D. T., Lastini, B. N., Khairunnisa, \& Amani, H. (2016). Actor Identification that Affects Ridwan Kamil's Work Program for Smart City Using Social Network Analysis. IOSR Journal of Business and Management (IOSR-JBM),, 18(4), 48-53.

Cahyaningrum, Y., Alamanda, D. T., Prasetio, P. A., \& Fitria, S. E. (2016). Study of Entrepreneurship Programs in Bandung Based on Ridwan Kamil's Twitter Account (@ridwankamil). OSR Journal of Business and Management (IOSR-JBM),, 18(4), 76-80.

George, G. F. (2004). Computers in Society: Privacy, Ethics \& the Internet. Upper Saddle River: Prentice Hall.

Giffinger, R., Fertner, C., Kramar, H., Kalasek, R., Pichler-Milanovic, N., \& Meijers, E. (2008). Smart Cities Ranking of European medium-sized cities. Copenhagen: University of Copenhagen.

Goldstein, J. S., \& Pevehouse, J. C. (2014). International Relations (10 ed.). Washington: Pearson.

Hardjaloka, L. (2014). Implementation Study on E-Government in Indonesia and Other Countries As A Solution in Eradicating Corruption in Public Sector. Jurnal Rechtsvinding, 3(3). Retrieved from kominfo.kotabogor.go.id: (http://kominfo.kotabogor.go.id/index.php/post/single/27)

Kemendagri. (2016). BPPT Kota Bandung Luncurkan Aplikasi Pelayanan Perizinan via "Smartphone". (Kemendagri.go.id) Retrieved March 16, 2018, "rom http://www.kemendagri.go.id/news/2016/01/12/bppt-kota-bandung-luncurkan-aplikasi-pelayananperizinan-via-smartphone

Munoz, L. A., \& Bolivar, M. R. (2018). Experiences of E-Government Development Implementation in Developing Countries: Challanges and Solution. In International E-Government Development: Policy, Implementation and Best Practice (p. 3). Granada: Palgrave Macmillan. 
Nadapdap, N. Y., Alamanda, D. T., Prabowo, F. S., \& Ayuningtyas, H. G. (2015). Measuring The Effectiveness Of Government Communication On Bandung Smart City (The Study On @ Ridwankamil Twitter Account During The Period Of 16 September 2013 To 31 July 2015). (Vol. 21). 72-79.

Reddict, C. G. (2011). Politics, Democracy, and e-government: Participation and Service Delivery. New York: IGI Global Snippet.

Silva, B. N., Khan, M., \& Han, K. (2018). Towards sustainable smart cities: A review of trends, architectures, components, and open challenges in smart cities. Sustainable Cities and Society, 38, 697-713.

Townsend, A. M. (2013). Smart Cities: Big Data, Civic Hackers, and the Quest for a New Utopia. New York: Norton \& Company.

Whitte, J. L., Bentley, L. D., \& Dittman, K. C. (2004). Systems analysis and design methods. Boston: McGrawHill.

Zhao, F., Scavarda, A. J., \& Waxin, M. F. (2012). Key Issues and Challanges in e-government. An Integrative case study of the number one eCity in the Arab world. Information Technology for Development, 25(4), $395-422$. 